\title{
Kontestasi Identitas dalam Transisi Kaum Muda Indonesia
}

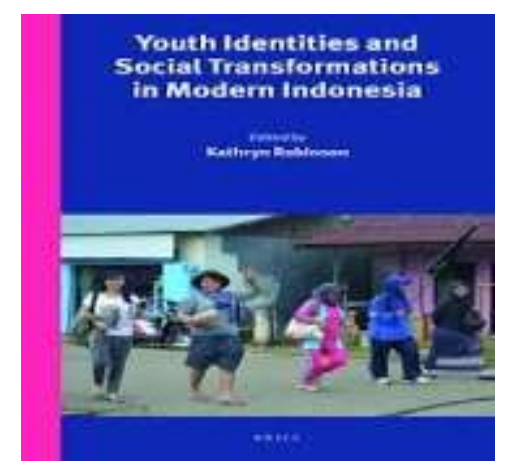

Editor : Kathryn Robinson

Penerbit: Brill Leiden

E-ISBN 9789004307445

Halaman: 287

Tahun 2016

Judul asli : Youth Identities and Social Transformation in Contemporary Indonesia

Buku ini menarik untuk disimak karena kita bisa belajar dari cara pandang para indonesianis dunia dalam melihat kaum muda di Indonesia. Selain itu, buku ini juga menebar banyak teori kepemudaan maupun metodologi riset yang menggabungkan dua pendekatan kuantitatif dan kualitatif. Sistematika buku ini terdiri dari enam bagian, masing-masing bagian terdapat dua artikel pilihan yang mengajak pembaca melihat dinamika kontestasi identitas dalam transisi kaum muda Indonesia, di awali dengan pembacaan tentang definisi pemuda dalam berbagai dimensi. Mulai dari perkembangan sosialnya, maupun interaksinya dengan relasi kuasa yang ada disekitarnya. Sebagai sebuah hasil riset, buku ini menawarkan gambaran besar kaum muda dalam tautannya dengan dimensi sosial-politik. Meskipun kaum muda dalam buku ini ditegaskan dalam pengantarnya berkorelasi secara multi disiplin, hal ini terungkap dalam pandangan Ben White di bagian pertama buku ini menjelaskan kaum muda yang ditinjau secara luas dalam berbagai literatur "studi kepemudaan". Diakui White hal itu memberikan efek pergeseran terminologi dan variabel yang digunakan dalam berbagai literatur, termasuk "pemuda" dan "masa remaja", tidak secara otomatis sesuai dengan istilah Indonesia seperti pemuda, remaja, dan dewasa, atau istilah yang lebih kekinian seperti $\mathrm{ABG}$ 
(Anak Baru Gede:"anak-anak yang baru tumbuh").

Selanjutnya, remaja adalah istilah yang relatif baru yang menyiratkan kedekatan hubungan dengan orang tua, dan perkembangan kebebasan selama masa sekolah, argumen ini terus berkembang bersamaan dengan keterlibatan remaja dalam perilaku konsumsinya. Sedangkan pemuda, seperti disebutkan di atas bisa jadi adalah istilah yang lebih politis dan global bagi generasi muda (termasuk remaja), semata hal tersebut terkait dengan masa transisi menuju dewasa. Selain itu, pemuda/remaja dianggap sebagai sosok yang dapat mengubah sesuatu, dimulai dari karya yang bersifat sosial sampai dengan keterlibatannya dengan gaya hidup yang diperoleh dari teman sebayanya maupun informasi yang mereka dapatkan dari TV, buku dan Majalah, internet atau media lainnya: intinya "Mereka mulai melepaskan diri dari dunia orang tua dan orang dewasa serta merasakan kebutuhan untuk tidak dikendalikan olehnya". White juga berpendapat bahwa para akademisi dan pembuat kebijakan sebaiknya menganggap pemuda sebagai aktor kunci dalam perubahan sosial dengan mengedepankan hak mereka sendiri, dan dalam hubungannya dengan orang dewasa. Sosok pemuda menetapkan sebuah posisi yang diambil oleh para penulis dalam buku ini yang memberikan koreksi terhadap beberapa kecenderungan akademisi menulis tentang pemuda dalam hubungannya dengan stereotipe populer seputar pemuda.

Garis besar bagian pertama buku ini mencoba memberikan wawasan tentang upaya mengkaji pengalaman pemuda Indonesia dengan menggunakan pendekatan sosial. Bagaimana hasilnya, Ben White menjelaskan gambaran kaum muda Indonesia dalam tinjauan yang luas tentang literatur "studi kepemudaan" seperti yang telah di sampaikan di atas. Senada dengan Ben White, gambaran besar tentang pemuda Indonesia juga ditunjukkan hasil riset Pam Nilan yang bertajuk "cuplikan" nasional siswa SMA, merupakan hasil survei yang dilakukan oleh Tim Ambivalent Adolescents in Indonesia (AAI), yang melibatkan purposive sampel siswa SMA dari sembilan lokasi di seluruh nusantara. Sebagian besar lokasi tersebut dieksplorasi secara etnografi dalam tulisan Bennett, Parker, Robinson, Wright Webster. Hasil survei dikontekstualisasikan dalam tinjauan riset terbaru pemuda di Indonesia Survei AAI membandingkan pandangan anak usia 16 sampai 18 tahun dari kota dan pedesaan, dan dari sekolah Islam dan sekuler, di semua komunitas yang berada di lokasi riset anggota tim peneliti AAI juga melakukan studi etnografi. Survei ini juga meneliti tren dan kesamaan dalam kehidupan orang muda Indonesia dalam dekade pertama milenium baru, terutama di ranah harapan hidup, kehidupan sosial, budaya populer, rekreasi, seksualitas, pendidikan, dan masuk kerja. Khususnya harapan hidup, Pendidikan, dan masuk kerja, dalam konteks transisi ke kedewasaan di negara Muslim terbesar di dunia ini. Istilah "transisi" di sini mengacu pada perjalanan dari pendidikan ke masa dewasa, pekerjaan atau karir, pernikahan, dan orang tua, ini juga terlihat dalam tulisan White. Analisis yang disajikan di sini didasarkan pada data survei AAI yang dikumpulkan di 2007 dari 3565 pemuda Indonesia di sekolah menengah dan universitas antara tahun 2006 dan 2008. Salah satu temuannya adalah kaum muda menyuarakan sesuatu yang popular tentang teman sebayanya, khususnya kecemasan 
tentang menurunnya moralitas, mereka tidak menganggap kekhawatiran ini berlaku untuk diri sendiri atau teman mereka.

Bagian kedua buku ini masih membahas pendidikan dan transisi sampai dewasa di dua komunitas yang sangat berbeda yakni di pedesaan Jawa dan Kota pertambangan di pedalaman Sulawesi. Merespon kedua kasus di Jawa dan Sulawesi tersebut, setidaknya penulis di Bab ini berpikir bahwa kaum muda harus pergi ke pusat Kota untuk melanjutkan pendidikan mereka. Kondisi tersebut terjadi salah satunya dikarenakan de-agrarianisasi tanah di Jawa, artinya hanya ada sedikit pekerjaan di pedesaan dan kaum muda harus pergi ke Kota untuk mencari pekerjaan. Kemudian Sekolah, ditambah dengan pengaruh media-massa, telah mengubah pemuda pedesaan di Jawa menjadi manusia siap untuk bekerja di perkotaan, khususnya pekerjaan industri. Sedangkan, tingkat pengangguran secara nasional masih tinggi di kalangan pemuda yakni sekitar 30 persen, dan sangat tinggi untuk lulusan universitas, data terbaru menurut Badan Pusat Statistik Indonesia sampai periode Agustus 2016-2017 khusunya lulusan pendidikan vokasi baik sekolah menengah dan kejuruan maupun diploma I-III, membengkak sekitar 11,41 persen menjadi pengangguran terbuka.

Pemuda yang telah bermigrasi menghadapi kesulitan dalam mencari pekerjaan, prasyarat pendidikan untuk mendapat pekerjaan ternyata tidak lagi sesuai, sebagai contoh, ijazah sekolah menengah pertama sudah tidak mencukupi untuk mendapat pekerjaan di pabrik. Selanjutnya, Kathryn Robinson dalam tulisannya memberikan kasus deagrarianisasi yang diilustrasikan oleh pemuda Kota pertambangan Sorowako, bagi penulis lokasi ini ideal untuk menunjukkan tempat pengembangan industri yang merujuk pada penghancuran ekonomi pertanian setempat. Untuk anak muda dari Kota, "kehidupan yang baik" adalah bisa kembali rumah untuk bekerja bagi perusahaan pertambangan dan tinggal di dekat keluarga di rumah mereka dan berada di wilayah leluhur. Padahal mereka telah melakukan self-fashioning yang diperlukan untuk transisi ke masa dewasa modern tetatpi tetap saja tidak cukup untuk mendapatkan pekerjaan, terutama pada tingkat yang sepadan dengan pendidikan mereka.

Ada pernyataan yang menarik dari bagian ketiga buku ini, yakni ilustrasi penulis tentang "pengalaman sekolah bukan hanya tentang membangun masa depan yang sukses, sebaliknya bersekolah juga menawarkan pengalaman dalam dunia sosial pula". Focus utama pernyataan di atas adalah persahabatan memainkan peran penting dalam membantu kaum muda di masa transisi mereka menuju masa dewasa, dan ini adalah fokus utama kedua tulisan di bagian ini yang ditulis oleh Lyn Parker dan Pujo Semedi, dan hal itu juga muncul bab lainnya. Parker menekankan persahabatan itu mengisi celah penting pada saat terjadi perubahan yang cepat kaum muda mengalami aspek transisi sampai dewasa yang berbeda dan tidak biasa untuk orang tua mereka. Parker mengidentifikasi persahabatan sebagai lacunae dalam studi antropologi kaum muda di masyarakat nonBarat. Dengan latar belakang wawancara ilmiah tentang persahabatan, dia menyajikan persahabatan dalam dua dimensi kegembiraan dan kepedihan wanita muda di sebuah Kota kecil di Sumatera Barat. Penulis menunjukkan hal yang signifikan antara peran hubungan sejawat dalam memfasilitasi transisi menuju masa dewasa, seperti teman sebaya saling 
mendukung dengan pengetahuan dan dalam mencari pengalaman baru dan pentingnya persahabatan. Sementara di banyak wilayah di Indonesia ada tradisi panjang kaum muda yang meninggalkan rumah untuk pendidikan, kondisi ini bisa jadi berkaitan dengan terjadinya perluasan partisipasi sekolah dan de-agrarianisasi seperti yang di sampaikan dalam tulisan bagian kedua buku ini.

Di sisi lain, Pujo Semedi meneliti pramuka sebagai organisasi yang menciptakan kesenangan dan persahabatan dalam hubungan sejawat. Meskipun di "Cap" sebagai organisasi korporat Orde Baru, dan ketinggalan zaman. Bahkan dianggap "tidak keren" oleh banyak kaum muda. Akan tetapi studi etnografi Semedi menunjukkan Pramuka sebagai organisasi "benar secara moral" dalam arti disetujui oleh orang tua. Mereka mencari beberapa keterampilan yang diperlukan dalam masa transisi sampai dewasa. Misalnya, beberapa aktivitas mewakili kegiatan bersenangsenang sambil belajar keterampilan seperti organisasi, manajemen, kepemimpinan, bermain peran, kerja kelompok, dan penyelesaian masalah. Juga merupakan ruang kesetaraan jender dimana anak perempuan dan anak laki-laki dapat melakukannya dan keduanya mengambil posisi kepemimpinan. Kedua tulisan di bagian ini menunjukkan pentingnya hubungan antar sesama dan perkembangan moral di luar lingkup hubungan kerabat. Kegiatan Pramuka dan sosialisasi informal terhadap perempuan muda, dalam studi Parker keduanya menyediakannya konteks untuk pencampuran jenis kelamin, termasuk dalam hal percintaan. Saya sepakat jika kedua tulisan ini, dan dalam beberapa bab lain dalam buku ini, telah menunjukkan peran penting kaum muda sebagai "wali moral" masing-masing, karena tekanan teman membuat kaum muda tetap aman dari beberapa bahaya moral. Dengan demikian, persahabatan dan aktivitas kelompok sebaya muncul sebagai penyediaan ruang kritis untuk transisi menuju masa dewasa.

Bagian keempat buku ini mencoba mendiskusi kaum muda dalam sebuah ruang, yakni ruang sosial bersifat membatasi dan memungkinkan berkenaan dengan kegiatan kaum muda serta otonominya. Penulis di bagian ini membahas dua jenis konsep sosial ruang yang berbeda. Guinness membahas perubahan penunjukan ruang dan tempat sosial di perkotaan dan pedesaan di Yogyakarta selama beberapa dekade dan cara-cara yang berdampak pada hal ini kegiatan pemuda, sementara Nilan mengeksplorasi pemuda bersosialisasi dengan apa yang dia sebutkan Ruang "private-public" di pusat perbelanjaan dan kafe internet, juga di memperluas ruang sosial yang dimungkinkan oleh Information Communication Technology (ICT). Selain itu, kedua penulis juga menjelaskan tentang konsep waktu. Misalnya Guinness mengeksplorasi satu lokasi pinggiran Kota selama empat dekade, menunjukkan perbedaan kendala dan peluang bagi setiap generasi yang telah dilalui kaum muda, "sementara Nilan mengeksplorasi dimensi waktu pengalaman sosial di lokasi tetap seperti Mal dan cyber-cafe. Ruang sosial ini berubah karakter dan digunakan untuk berbagai jenis sosialisasi sepanjang hari dan malam. Kedua penulis menyoroti perbedaan gender dalam penggunaan ruang, dengan anak laki-laki Membiarkan lebih banyak kebebasan daripada anak perempuan, tapi ruang mal dan kafe itu memungkinkan kaum muda, yang diilustrasikan oleh gadis kelas menengah untuk bersosialisasi dalam kelompok, 
termasuk di kelompok dengan jenis kelamin yang berbeda. Mal adalah ruang penting bagi pengalaman pemuda kelas menengah, sebagaimana adanya zona interaksi orang tua. Mereka menyediakan tempat kerja dan juga ruang rekreasi Mengambil tema yang dieksplorasi dalam tulisan lainnya buku ini seperti dikatakan Parker, Bennett, gadis-gadis muda yang diteliti oleh Nilan merasa terlindungi ruang rekreasi modern ini dengan nilai religius dan praktik saleh mereka juga oleh peer surveillance. Tulisan Nilan juga menyajikan "gaya hidup" yang banyak dibahas, teridentifikasi dengan konsumsi dan berkembangnya kelas menengah. Bahasan yang sama sebenarnya juga ditunjukkan di bab lainnya buku ini, yang juga mendiskusikan kegiatan rekreasi di kalangan anak SMA seperti tulisan Wright Webster, dan Parker. Tema penting dalam tulisan Guinness adalah karakter berbasis pengalaman kelas pemuda yang berdampak pada peluang seperti pendidikan dan pekerjaan, serta pada pandangan dan gaya hidup. Kaum muda di Yogyakarta yang dia diskusikan dibagi oleh kelas, dan mereka terlibat dalam konflik lintas kelas. Menariknya, salah satu fokus konflik kelas adalah pencampuran jenis kelamin (terutama laki-laki kelas menengah dalam hubungan seksual dengan gadis kelas bawah), dan peer surveillance dibahas dalam di bagian sebelumnya. Bagi kaum muda di komunitas yang dia teliti, kelas dinyatakan dalam istilah spasial (kampung versus gedhongan), yang notabene mengacu pada perbedaan antara kelas bawah yang miskin dan kelas menengah perkotaan, dan dengan metafora perpanjangan, gaya hidup dan kesempatan hidup. Intinya adalah sebuah cerita yang berlangsung lebih dari 40 tahun di lingkungan perkotaan kelas bawah tertentu, dan cara "ruang" pemuda telah berubah melalui dampaknya perubahan rezim di pusat, dan mobilitas masyarakat.

Bagian kelima buku ini menjelaskan penanda peralihan demokrasi ditandai oleh menjangkitnya komunalitas dan kekerasan antar agama, sebagian besar dilakukan oleh kaum muda. Kedua penulis di bagian ini mengambil dua kelompok yang sangat berbeda yang memiliki wilayah teritorial untuk mengekspresikan identitas pemuda/maskulin mereka, yakni siswa kelas menengah di Yogyakarta yang tertarik pada milenarian janji kelompok Islam radikal Hizbut Tahrir Indonesia (HTI), dan kelas rendah muda pria di Ambon pasca konflik. Kedua tulisan tersebut menggambarkan bagaimana kelompok ini pria muda mengukir ruang sosial untuk beraksi di jalan melalui penggelaran simbol. Dalam kasus Ambon, dijelaskan oleh Spyer, kaum muda melukis billboard raksasa yang dibajak dengan gambar bertemakan agama yang menaungi jalan dan menandai sebuah domain kekristenan. Aktivis HTI menyebarkan simbol-simbol Gaun, bendera, dan spanduk yang terinspirasi Arab untuk menandai ruang protes itu mereka menempati dalam upaya untuk mengacaukan negara sekuler. Sementara satu gaya tindakan reaktif ditunjukkan dalam gambar Jesus di papan reklame, keduanya menulis tentang mimpi dan kesulitan yang dihadapi kaum muda muda yang mengalami masa muda berkepanjangan di Indonesia modern namun tanpa menerima transisi ke masa dewasa modern perkembangan itu retorika dijanjikan Hasan berpendapat bahwa simbol Islam yang diambil oleh Pemuda Islam radikal merupakan alternatif identifikasi simbolis dari global simbol budaya konsumen yang ditawarkan kepada kaum muda. Begitu pula pria muda di 
Ambon "menempati" ruang billboard, yang sampai sekarang digunakan untuk iklan janji budaya konsumen, untuk secara visual menandai ruang mereka. Esai foto Spyer dapat dibaca sebagai tanggapan atas klaim White di bagian awal buku ini yakni "Suara kaum muda pantas didengar". Dalam konteks ini kaum muda telah memiliki suara meski melalui media visual.

Bagian terakhir buku ini menjelaskan problematika kaum muda Indonesia yang terbentuk dari generasi penerus "generasi pembawa bangsa ini maju ke masa depan". Sebaliknya muncul wacana populer lainnya mencirikan kaum muda Indonesia memiliki moral patologis. Seiring ekonomi Indonesia tumbuh lebih makmur dan terbuka bagi perekonomian dunia, sebuah pandangan telah muncul dalam wacana publik mengenai hal-hal yang merusak dampak "globalisasi" terhadap kaum muda. Dalam pandangan alternatif ini, kaum muda menyajikan sebuah risiko. Dalam satu framing populer, anak muda (remaja) ditafsirkan sebagai korban pengaruh budaya dan ideologis Barat, dan dugaan mereka perilaku transgresif "seks bebas", penggunaan alkohol dan narkoba yang dianggap melemahkan kesehatan bangsa. Hal ini berhubungan dengan hasil survei AAI yang ditulis oleh Nilan dkk dalam buku ini tampaknya secara kolektif mengarah pada kekhawatiran tentang ancaman perilaku menyimpang tersebut (pergaulan bebas atau interaksi sosial bebas). Namun hasil survei menunjukkan bahwa meskipun mereka mencantumkan ini sebagai "isu patologis" mereka tidak melihat diri mereka atau teman sebayanya sebagai bagian dari masalah. Kontradiksi ini dieksplorasi secara lebih mendalam oleh Wright Webster melalui kelompok fokus dan wawancara dengan orang muda di Yogyakarta saat dia mengikuti sampai pada survei alih-alih merasa bahwa mereka merespons, atau terpengaruh dengan praktik budaya asing, mereka menganggap diri mereka bertanggung jawab dan menjalankan kebebasan individu, bahkan jika menyangkut pilihan seksual dan perilaku yang tampaknya melanggar standar normatif yang seharusnya mereka generasi orang tua. Dan jauh dari melihat diri mereka sebagai korban "Barat", Mereka mengidentifikasi masalah yang timbul karena institusi masyarakat Indonesia-seperti keluarga mereka atau sistem pendidikan negara - dianggap telah mengecewakan mereka. Ini tidak berbeda dengan gambaran yang muncul dalam studi Bennett tentang kaum muda Lombok.

Di Lombok perkawinan muda dianggap fenomena sosial yang memprihatinkan dan sering dikaitkan dengan kebebasan kaum muda yang berlebihan. Menariknya suku Sasak adalah salah satu komunitas yang mempunyai norma menikahkan perempuan di usia muda. Disamping muncul wacana pergaulan bebas dianggap bagian dari nilainilai Barat yang meresap dan mengancam kehidupan sosial masyarakat Indonesia, analisis etnografi Bennett menunjukkan bahwa kebanyakan pernikahan muda di Lombok bukanlah "solusi" untuk masalah kehamilan dan pernikahan. Dia memisahkan isu awal pernikahan dan kehamilan remaja, karena penulis menemukan bahwa itu bukan alasan untuk remaja ini menikah karena mereka hamil. Artinya sebenarnya perempuan muda Lombok tahu bahwa pergaulan mereka bisa jadi membawa resiko sosial tertentu. Ditegaskan oleh Bennett yang menemukan perempuan muda membuat pilihan positif dalam budaya dan sosial mereka sendiri dan konteks ekonomi seperti kemiskinan, pendidikan dan kesempatan kerja yang 
kurang, dan norma sosial tentang transisi ke masa dewasa menggarisbawahi pilihan yang dilakukan wanita muda ini menjadi istri dan ibu muda. Perempuan muda di Lombok tidak menganggap awal kehamilan dan persalinan sebagai sesuatu yang berisiko atau berbahaya, sayangnya intervensi pembangunan diarahkan untuk mencegah pernikahan dini, hal ini berlawanan dengan kekhawatiran konsep Barat yang merusak.

Pemahaman para penulis buku ini dalam menyusuri dinamika kaum muda Indonesia, telah menawarkan pembacaan kaum muda dari sisi yang berbeda. Hal ini memberikan pengetahuan baru untuk melihat dinamika kaum muda secara menyeluruh di Indonesia, pendekatan yang dipakai penulis-pun seolah merangkaikan sebuah catatan panjang tentang transisi kaum muda secara utuh dan khas indonesianis, hal ini ditunjukkan dengan pilihan isu dan metodologisnya yang masing-masing penulis mempunyai jam terbang yang tinggi dalam pilihan topik yang ditulis. Sayangnya masih belum muncul pilihan isu kaum muda kreatif, lingkungan, kewirausahaan, digital dan kebijakan yang saya yakin akan memberikan kesan millenial kaum muda Indonesia sebagai pelaku (subject) yang lebih menonjol daripada hanya sekedar pembawa masalah. Selain itu, masih terkesan beberapa penulis menganggap problematika kaum muda masih seputar analisis mikro dan mezzo saja. Kekuatan buku ini berada di proses refleksi dan intepretasi atas pengalaman penulis yang mempunyai budaya riset yang kuat dan mumpuni. Meskipun refleksi tersebut sebenarnya bisa menjadi pijakan pembuatan kebijakan nasional kepemudaan tetapi belum bisa dianggap mewakili keseluruhan kondisi kaum muda di
Indonesia. Dalam konteks ini penulis lebih menonjolkan kepentingan riset daripada kepentingan kaum muda sendiri. *** 